\title{
ROAD TRAFFIC MORTALITY IN RUSSIA: DEFINITIONS, TRENDS AND PERSPECTIVES
}

\author{
ANASTASIYA PYANKOVA, TIMUR FATTAKHOV
}

\begin{abstract}
In 2016, the crude death rate from road traffic accidents in Russia decreased, according to police data, to a level not observed since 1971, after which it continued to decline. The positive trends apparently served as the basis for the optimistic goals laid down in the Road Safety Strategy for 2018-2024.

Based on police data, vital statistics on mortality and international databases on mortality and road safety, the authors try to answer these questions: Are the goals set achievable within the specified timeframe, and how consistent are they with European trends in road traffic mortality, as well as with Russia's present differentiation of road traffic mortality by space, age and category of road users?
\end{abstract}

The study showed that the deadlines for achieving targets in the Road Safety Strategy are very tight. Today, only large and medium-sized cities have the potential to implement a new Road Safety Strategy in which the crude death rate should not exceed 1.5-2 deaths per 100 thousand people by 2024, whereas in small cities and rural settlements - 2.5-3 deaths per 100 thousand people. For many years, the main risk groups have been drivers and passengers aged 15-44 and pedestrians over 60 years old, who do not appear in the Road Safety Strategy as priority categories.

In addition, the article shows that in order to eliminate the existing discrepancies between the numbers of deaths published by the two official reporting systems (the police and Rosstat), the very first step might be for Rosstat to stop calculating the number of road traffic deaths based on the current version of the abridged classification of causes of death and transition to one of the two international approaches for aggregating three-digit codes of causes of death used by the WHO.

Key words: road traffic accidents, road safety, road traffic mortality, police data, vital statistics.

\section{INTRODUCTION}

In contrast to European countries, where since the 1970s there has been a consistent decrease in mortality from road traffic accidents (RTAs), in Russia the long-term dynamics of road traffic mortality are wave-like. Russia has maintained a positive trend in the decline in road traffic mortality that has developed since 2004 .

In 2016, the crude death rate (CDR) from road traffic accidents according to the police data and the standardized mortality rate (SDR), based on vital statistics, which had previously fluctuated, reached historic lows (13.9 and 12.6 deaths per 100 thousand people, respectively) after which they continued to decline.

Anastasiya Pyankova (apyankova@hse.ru), National Research University Higher School of Economics, RUSSIA.

Timur FatTakhov (tfattahov@hse.ru), National Research University Higher School of Economics, Russia.

THE STUDY WAS IMPLEMENTED UNDER THE GRANT FROM RUSSIAN FOUNDATION FOR BASIC RESEARCH NO. 19-013-00060 «ROAD-TRAFFIC MORTALITY IN RUSSIA AND ITS REGIONS: ANALYSIS BASED ON LINKED POLICE ROAD-CRASH RECORDS WITH MORTALITY STATISTICS».

THE ORIGINAL ARTICLE IN RUSSIAN WAS PUBLISHED IN DEMOGRAPHIC REVIEW 2019. 6(3): 58-84.

DOI: 10.17323/DEMREVIEW.V6I3.9855 
Apparently, the recent trends have formed the basis for the optimistic targets adopted in the Road Safety Strategy (RSS) ${ }^{1}$ : reducing the crude death rate to 4 deaths per 100 thousand people by 2024 and striving for a zero mortality rate by 2030 .

Based on the data on road traffic deaths from the two reporting systems in Russia (the police and the Federal State Statistics Service), as well as international databases on mortality and road safety, the authors try to answer the following questions: are the targets achievable within the timeframe proposed in RSS and, if so, for which regions and types of road users; how are the targets in RSS in line with international road traffic mortality trends.

However, before answering these questions, it is necessary to consider the different approaches to the definition of a road traffic death in the two reporting systems, its variations within them and the compliance of these definitions with international ones, as well as to explain the discrepancy in the number of deaths in road traffic accidents between those reporting systems in Russia.

\section{THE DEFINITION OF A ROAD TRAFFIC DEATH IN DIFFERENT REPORTING SYSTEMS}

According to the Road Safety Strategy, the indicator evaluating its effectiveness is the crude death rate due to road traffic accidents calculated on police data ${ }^{2}$. In Russia, as in many countries of the world, there are two main reporting systems for those who died in road traffic accidents: the police and the Federal State Statistics Service. Whereas the definition of a person killed in a road traffic accident applied by the police has not changed significantly since the ratification of the Vienna Convention on Road Traffic of 1968, the corresponding definition in vital statistics depends on the current version of the abridged classification of causes of death.

The International Classifications of Diseases (ICD) were never directly applied in the USSR. The versions of the abridged classifications of causes of death existing in the USSR were adapted to the ICD, but significantly differed from it. From 1965 to 1988, there were 4 versions of abridged classifications of causes of death in the USSR. A feature of three of them (those of 1965, 1970 and 1981) was the division of external causes of death into occupational and nonoccupational accidents, including all categories of transport accidents (Table A1 of the Appendix). Occupational accidents along with some other causes of death were listed separately in a secret statistical table (Table 5b), while the remaining causes were tabulated in Table 5. The situation changed after the revision of the classification of 1988, which was in use until 1998, where this division was abolished and the statistical tables №5 and №5b were replaced by a single statistical reporting form C-51, "Distribution of the deaths by gender, age group, and cause of death" (Mesle et al. 1996). In the last version of the Soviet abridged classification of 1988, transport accidents were divided into three categories: 1) motor vehicle traffic accident; 2) motor vehicle traffic accident involving collision with a pedestrian; 3 ) other transport accidents. Meanwhile, in an ICD-

\footnotetext{
${ }^{1}$ Decree of the Government of the Russian Federation of January 8, 2018 No. 1-r "Road Safety Strategy in the Russian Federation for 2018-2024”.

${ }^{2}$ Hereinafter, by the police we mean the traffic police of the Ministry of Internal Affairs of the Russian Federation. 
9 basic tabulation list transport accidents (E470) were divided into five groups: 1) motor vehicle traffic accidents; 2) other road vehicle accidents; 3) railway accidents; 4) water transport accidents; 5) air and space transport accidents.

After the dissolution of the USSR, from the beginning of the 1990s aggregate mortality statistics by causes of death started to be transmitted to the World Health Organization (WHO). The European detailed mortality database (DMDB) provides data on the number of deaths in motor vehicle traffic accidents from 1980 to 1998 in Russia. The number of deaths within 1) motor vehicle traffic accident and 2) motor vehicle traffic accident involving collision with pedestrians was considered by WHO as killed in «motor vehicle traffic accidents» for the period 1980-1998. From 1988 to 1998 the number of deaths in Russia in motor vehicle accidents extracted from DMDB and the number of deaths due to road traffic accidents according to the Russian police, do not differ significantly (the blue and dark blue lines in Figure 1, respectively). Therefore, the definitions of death due to road traffic accidents applied by Russian police and WHO within DMDB could be considered synonymous.

The situation changed with the introduction of ICD-10, where the differentiation of the transport causes of death associated with land-based non-rail modes of transport became more detailed. In ICD-9, motor vehicle traffic accidents included all accidents involving motor vehicles. In ICD-10, a distinction between the categories of road users was made: a pedestrian, a cyclist, a motorcyclist and a person in a vehicle. Unlike ICD-9, the types of vehicle are differentiated in detail. Instead of the general notion "motor vehicle", the following types of land transport were used: pedal cycle; two- or three-wheeled motor vehicle; car, pick-up truck or van; heavy transport vehicle or bus and other types of transport modes. The most detailed fourth digit specifies simultaneously both the category of the road user located on/in the vehicle (driver, passenger or unspecified as a driver or a passenger person), and the place of the accident (traffic, non-traffic or unspecified as a traffic or non-traffic accident). WHO determined a set of the following three-digit ICD-10 codes which would correspond to the deceased in a "motor vehicle traffic accident" from ICD-9, to maintain the comparability of the time series: V02-V04; V09; V12-V14; V20-V79; V82V87; V89 3 . In addition, WHO in "Global Health Assessments" uses another set of 3-digit codes to distinguish the number of people killed in "road injuries": V01-V04; V06; V09-V80; V87; V89; V99. A set of 4-digit codes is also specified to distinguish the number of people killed in "road injuries" (World Health Organization 2018b: 69).

ICD-10 came into force in 1999 in Russia, and correspondingly, a new Russian abridged classification (RC) was introduced. Since then, it has been revised three times (table A2 in the Appendix).

In the first RC of 1999 following the ICD-10 the criteria for grouping transport codes changed. The following three items were introduced in RC-1999: 1) a pedestrian injured in a transport accident; 2) car occupant injured in a transport accident; 3) other and unspecified transport accidents. Similarly to the SC-1988, in the RC-1999 «transport accidents» comprised 3 items, but they were not identical to the previous ones. Therefore, there is no easy way to

\footnotetext{
${ }^{3}$ https://gateway.euro.who.int/en/indicators/hfa_167-1740-sdr-motor-vehicle-traffic-accidents-all-ages-per-100000/visualizations/\#id=19098\&tab=notes (accessed 13 September 2019).
} 
continue a time series using the definition «motor vehicle traffic accidents». Presumably, this interruption in the time series affected the possibility of publishing data on the number of deaths in RTA in the "Demographic Yearbook of Russia". Hence only the total number of deaths in all transport accidents was published in 1999 - 2005.

In the second RC-2006, each of the previous items was subdivided into fatalities in traffic and non-traffic accidents, depending on the $4^{\text {th }}$ digit of the ICD-10 code. Rosstat determined the total number of deaths coded by items 239, 240 and 241 from RC-2006 as the number of deaths due to road traffic accidents and started to publish this figure in the "Demographic Yearbook of Russia". The number of deaths in road accidents (the red line in Figure 1), defined in this way, was significantly lower compared to the police data (in 2006, 22.1 thousand people against 32.7 thousand, respectively).

An attempt to get a coherent cause-specific time series under the same RC was made in the Human Cause-of-Deaths Database $(\mathrm{HCoD})^{4}$, using a reconstruction method. HCoD provides data on Russia for the period from 1956 to 2014 in line with the Russian abridged classification in use in 2006-2010.

In 2011, a new expanded abridged classification was introduced (the RC-2011). As before, new detailed categories are mostly the result of division of the broader items from the RC-2006. However, it doesn't concern «transport accidents», as a new classification criterion was introduced within V-codes (Danilova 2015). Firstly, an aggregation was made according to the $3^{\text {th }}$ character of the ICD-10 code defining the category of road user (pedestrian; pedal cyclist, motorcyclist and occupant of a three-wheeled motor vehicle; occupant of a motor vehicle (car, pick-up, heavy transport vehicle, bus)). Then, the same was done for the $4^{\text {th }}$ digit of the ICD-10 code defining the place of the accident (traffic, non-traffic, unspecified whether traffic or non-traffic accident). As a result, all transport accidents comprised 13 items instead of the previous 6 (Table A2 in the Appendix). The sum of 3 items (256, 257, 257 from Table A2 in the Appendix) are defined by Rosstat as the number of deaths in road traffic accidents and published in the "Demographic Yearbook of Russia" (Federal Service ... 2017). Therefore, there is a different combination of ICD$10 \operatorname{codes}^{5}$ under the same name. This approach indicates a non-inclusion of both all non-traffic accidents and pedestrians who died in an unspecified whether traffic or non-traffic accident. It corresponds neither to any group of codes used by WHO for defining the number of fatalities in road traffic accidents, nor to the previous definition in RC-2006. Possibly, for this reason the DMDB publishes the number of deaths in all transport accidents in Russia only starting from 1999.

The situation worsens due to peculiarities of coding a death due to road traffic accidents in the medical death certificate by forensic experts. There is a problem of determining the place of accident for forensic experts if the deceased was a pedestrian. Thus a significant number of such cases are coded as unspecified whether traffic or non-traffic accident (179 of 264 pedestrian deaths in Moscow in 2016) (Pyankova et al. 2019). Further, they are aggregated by Rosstat in RC-2011 items" a pedestrian injured as a result of an unspecified transport accident (except for a railway)" and are not considered as death due to road traffic accidents. A combination of these two facts

\footnotetext{
${ }^{4}$ https://www.causesofdeath.org/cgi-bin/country.php?country=RUS (accessed 13 September 2019).

${ }^{5}$ V01-V04(1); V09(2-3); V10-V18, V20-V28(3-9); V19, V29-V39(4-9); V40-V79(4-9); V83-V86(2). 
leads to an underestimation the number of death in RTA in Russia in statistical table C-51 and correspondingly in the "Demographic Yearbook of Russia" (Federal Service ... 2017; the red line in Figure 1).

Given the above, carrying out research on the long-term road traffic mortality in Russia based on the $\mathrm{RC}$ is highly problematic, as it would lead to wrong conclusions concerning even the up-to-date level of road traffic mortality, besides its evolution and composition. HCoD provides coherent time series only until 2014 under the out of use RC-2006 and does not allow the defining of road traffic mortality following one of the international approaches. Thus, we conduct our research on individual non-personalized data on the deceased aggregated along with the international approaches for identifying the number of deaths in road traffic accidents.

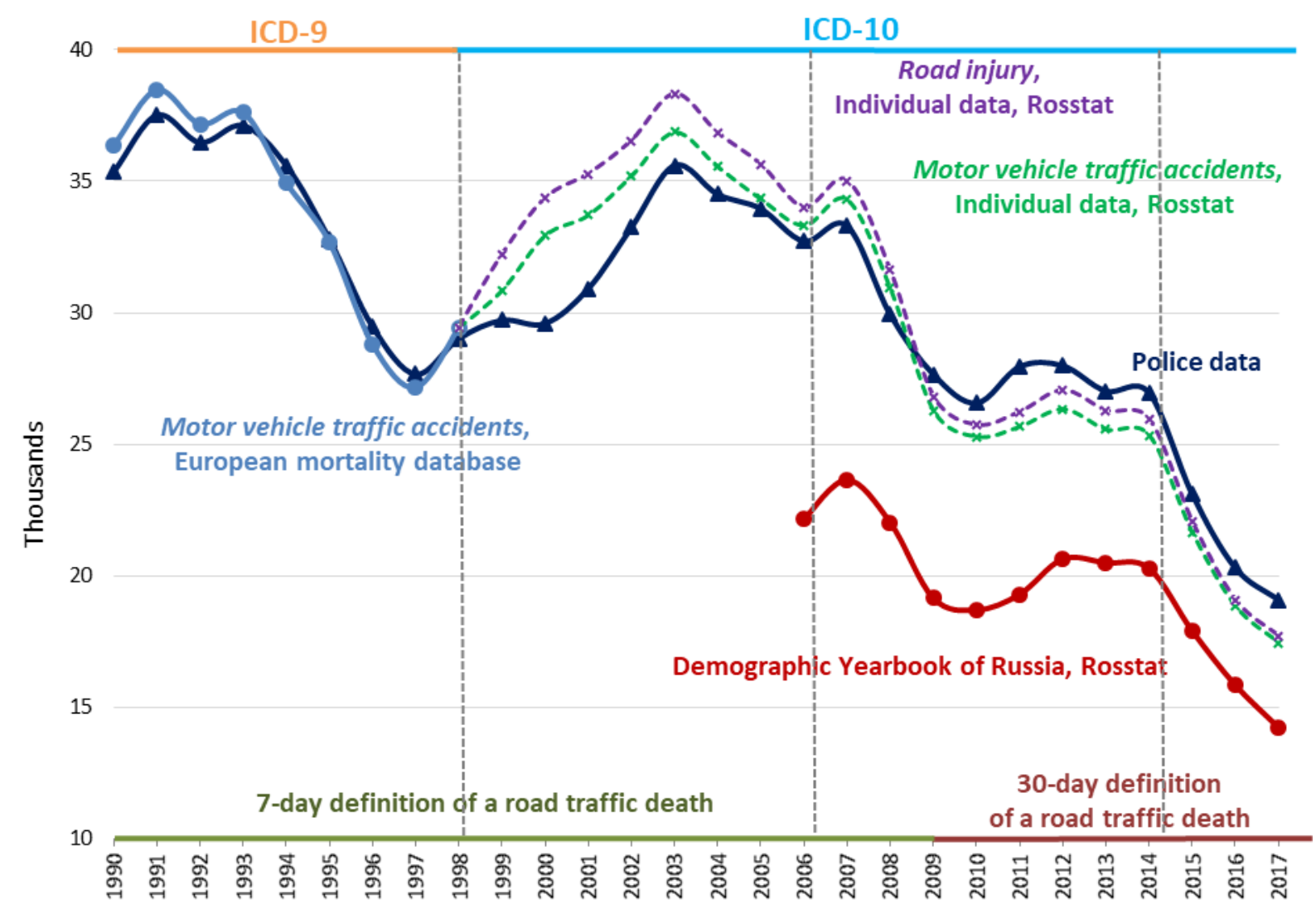

Figure 1. The number of deaths in road traffic accidents in Russia according to different data sources

Source: police data, Demographic Yearbook of Russia (Federal Service ... 2017), individual data from Rosstat, $D M D B$.

Beginning in 1999 the number of deaths in "motor vehicle traffic accident" and "road injuries" based on individual data from vital statistics (green and purple lines in Figure 1) differs from police data (dark blue line in Figure 1). The maximum number of discrepancies are observed during the transition from ICD-9 to ICD-10. From 1999 to 2008, the number of deaths in "motor vehicle traffic accident" and "road injuries" was higher than the figures provided by the police. Since 2009 it has been the reverse, probably due to the transition of Russia and the police registration system from a 7-day to a 30-day definition of the deceased in road traffic accidents. Unlike the above-mentioned discrepancy explained by a change in ICD revisions, simultaneous 
changes in responsibility for coding causes of death in the medical death certificates, a data capture system, a huge discrepancy exists between police data and data published in the "Demographic Yearbook of Russia" because of Rosstat's approach to defining the number of deaths in RTA (Danilova el al. 2016).

Table 1 presents a variety of estimates of the number of deaths in road traffic accidents in Russia in 2016 in line with two main data sources on fatalities in RTA and depending on the approach for aggregating detailed ICD-10 codes within vital statistics.

Table 1. The number of deaths in road traffic accidents in Russia in 2016, people

\begin{tabular}{|c|c|c|c|}
\hline \multirow[t]{2}{*}{ No. } & \multirow[t]{2}{*}{ State reporting systems } & \multicolumn{2}{|c|}{ The number of deaths depending on } \\
\hline & & $\begin{array}{l}\text { year of registration } \\
\text { of death }\end{array}$ & $\begin{array}{l}\text { year of } \\
\text { death }\end{array}$ \\
\hline 1 & Police reporting systems, Ministry of Interior Affairs & & \\
\hline 1.1 & The number of fatalities in road traffic accidents & 20308 & $\begin{array}{l}\text { Not } \\
\text { applicable }\end{array}$ \\
\hline 1.2 & $\begin{array}{l}\text { The number of fatalities in road traffic accidents adjusted for } \\
\text { accidents occurring off public roads }\end{array}$ & 19725 & $\begin{array}{l}\text { Not } \\
\text { applicable }\end{array}$ \\
\hline 2 & Vital Statistics, Rosstat: & & \\
\hline 2.1 & The number of deaths in road injuries, individual data: & & \\
\hline 2.1.1 & Three-digit ICD-10 codes & 19100 & 19186 \\
\hline 2.1.2 & Four-digit ICD-10 codes ${ }^{6}$ & 17431 & 17437 \\
\hline 2.2 & $\begin{array}{l}\text { The number of deaths in motor vehicle traffic accidents, } \\
\text { individual data }\end{array}$ & 18969 & 18948 \\
\hline 2.3 & $\begin{array}{l}\text { The number of deaths in motor road accidents (parts of V01-V89), } \\
\text { Demographic Yearbook of Russia }\end{array}$ & 15800 & 15805 \\
\hline
\end{tabular}

Source: police data, Demographic Yearbook of Russia (Federal Service ... 2017), individual data from Rosstat.

According to the representatives of the scientific center for road safety of the Ministry of Internal Affairs of the Russian Federation, the official number of deaths reported by the police includes some cases not in line with the definition from the Glossary for Transport Statistics (Economic Commission for Europe ... 2009: 93). Such events include cases that occurred off-road (a clearing, forest, field, the ice of a frozen pond; a car park separated from the carriageway; a multi-storey parking; an underground or underground constructions, etc.) or in closed areas outside of common use (quarry, airfield, pier, industrial, technological, service, warehouse or other administrative territory, including one used for driving on a dam). In 2016, according to the police, 583 similar accidents occurred (Bakanov 2019). Without considering these cases, the number of fatalities in road traffic accidents according to the police would be 19.7 thousand persons killed in 2016 (Table 1). A selection of three-digit ICD-10 codes (V01-V04; V06; V09-V80; V87; V89; V99) within the "road injury" definition in vital statistics provides the nearest assessment (19.1 thousand deaths in 2016) to the adjusted police data (19.7 thousand persons killed in 2016).

Using detailed mortality data, no fundamental contradictions on the number of deaths in RTA between the police and vital statistics have been observed. Thus it is justified to use both depending on the research objectives.

\footnotetext{
${ }^{6}$ V01-04.1-9;V06.1-9;V09.2-3;V10-14.3-9;V15-19.4-9;V20-28.3-9;V29-79.4-9;V80.3-5;V81.1;V82.1,8,9; V83-86.0-3;V87.0 9;V89.2,3,9;V99;Y85.0.
} 


\section{CONSISTENCY OF ROAD SAFETY STRATEGY WITH THE RUSSIAN AND EUROPEAN ROAD TRAFFIC MORTALITY TRENDS}

It is assumed that the crude death rate will decrease by 3.5 times during the implementation of the Road Safety Strategy and will not exceed 4 deaths per 100 thousand people by 2024. In 2017, a similar and lower level of road traffic mortality was observed in 13 countries: Great Britain, Germany, Denmark, Israel, Ireland, Spain, the Netherlands, Norway, Finland, Sweden, Switzerland, Estonia, Japan (IRTAD 2018). In the 1970s, in these countries the mortality rate ranged from 13 to 19 deaths per 100 thousand people, as in Russia in recent years. Only after 30 years did the mortality rate decrease to $4-5$ dead per 100 thousand people in these countries.

In the early 2000s, a completely new task was formulated under the auspices of the UN and WHO. The challenge was not another nosological one of infectious diseases, but one of the external causes of death - road traffic accidents and their consequences. The Global Sustainable Development Goals (SDGs) postulated a necessity to halve the number of global deaths and injuries from road traffic accidents by $2020^{7}$. In Europe in 2011 began the second wave of the global plan "Decade of Action for Road Safety 2011-2020"8 suggesting a reduction of the number of deaths from road traffic accidents in the European Union (EU) in accordance with the SDGs. The principles from the Swedish road safety conception "Vision Zero" are the basis for this plan. The conception was developed in 1997, when the number of deaths in road traffic accidents in Sweden was 541 people or 6 deaths per 100 thousand people. Within it, road traffic mortality is considered as completely preventable causes of death and injuries. With such a low level of road traffic mortality, the slogan "zero road traffic mortality" seemed justified and achievable. At the first stage of the concept, the aim was to reduce the number of deaths by $50 \%$ by 2007 relative to 1996. By the end of its implementation, the number of road traffic deaths had decreased by only $13 \%$. In 2017, the road traffic death rate decreased to 2.7 deaths per 100 thousand people after 20 years of "Vision Zero" implementation.

In Russia, under the Federal Target Programs (FTP) ${ }^{9}$ for 2006-2012 and 2013-2020 the planned decrease in the absolute number of deaths in road traffic accidents generally corresponded to similar plans in other countries (IRTAD 2018). The FTP for 2006-2012 assumed "a decrease in the number of people killed in road traffic accidents by 1.5 times by 2012 compared to $2004^{\prime \prime} 10$ or by 33\% compared to the baseline. In the next FTP for the 2013-2020 it was planned to "reduce deaths from road traffic accidents by 8 thousand people by 2020 compared to $2012, " 11$ or by $29 \%$ from the baseline.

A comparison of the targeted and actual number of deaths in road traffic accidents in the EU-28 countries shows that the actual reduction of road traffic deaths almost never reached the

\footnotetext{
${ }^{7}$ https://sustainabledevelopment.un.org/sdg3 (accessed 13 September 2019).

${ }^{8} \mathrm{https}$ ///www.unece.org/fileadmin/DAM/trans/roadsafe/docs/A-RES-64-255r.pdf (accessed 13 September 2019).

${ }^{9}$ In Russia, in the first Federal Target Program (FTP) for the period 1996-1998, reducing the number of deaths in road accidents was not the main goal, but was one of the tasks within the overall goal of improving road safety. It was also not specified by how much the number of deaths in road accidents should decrease.

${ }^{10}$ Decree of the Government of the Russian Federation of February 20, 2006 No. 100 "On the federal target program 'Improving road safety in $2006-2012$ '”.

${ }^{11}$ Decree of the Government of the Russian Federation of October 3, 2013 No. 864 "On the federal target program 'Improving road safety in 2013 - 2020'".
} 
targets (Figure 2). In Russia, the decrease in the number of road traffic deaths was at a faster pace than planned, and the target indicators of the second FTP were achieved earlier than the deadline.

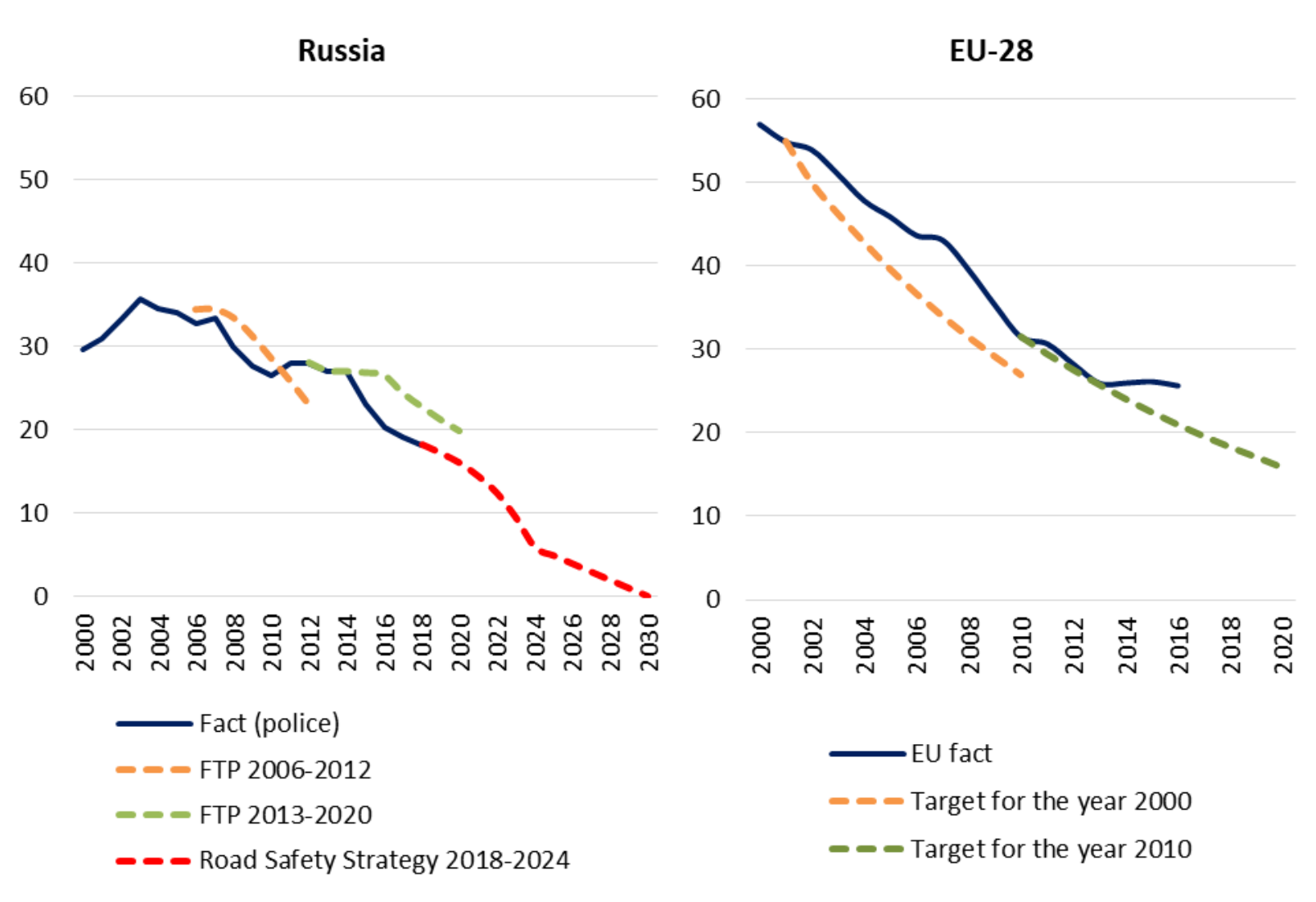

Figure 2. The targeted and actual number of deaths in road traffic accidents in Russia and the EU-28, thousand deaths

Source: Compiled from (European Commission 2017), police and federal target data.

The Road Safety Strategy for 2018-2024 was the first document to formulate the goal in term of mortality rates, not in absolute numbers (a reduction in the number of deaths per 100 thousand people). If we recalculate the mortality rate into the absolute number of deaths, using Rossat's medium population projection by 2030, it turns out that the absolute number of deaths in road traffic accidents should decrease by $68 \%$ over 7 years. The reduction should be more than 2 times more intense compared with previous programs. These figures are less consistent with the international targets for road traffic mortality reduction, which have never exceeded $50 \%$ over 10 years (IRTAD 2018). Moreover, in the EU-28, relying on the Vision Zero concept, the complete prevention of road traffic deaths is set as a goal only by 2050 (UN Road Safety ... 2010).

The international context shows that no one has managed to achieve such low mortality rates from road accidents (4 deaths per 100 thousand) in such a short time (7 years) as proposed by the Russian Road Safety Strategy. The required time period for reducing CDR from 13 to 4 deaths per 100 thousand people has varied from 33 years in Norway to 11 years in Spain (Table 2). The lower the level of road traffic mortality, the more time is required for its further reduction; the previous road safety measures in the new conditions no longer lead to such an intense decline. New drastic measures are needed to ensure further intensive reduction, involving more 
sophisticated infrastructural and urban planning decisions and, most importantly, changing people's behavior.

In conclusion, the goal of the Road Safety Strategy is consistent with the international agenda and national objectives, but the same cannot be said of the dates for its achievement.

Table 2. Required time for a reduction of road traffic CDR from 13 to 4 deaths per 100 thousand people in countries where it was lower than 4 deaths per 100 thousand people in 2017

\begin{tabular}{l|l|c|c|c|c}
\hline No. & Country & $\begin{array}{c}\text { Year when CDR } \\
\text { was 13 deaths per } \\
100 \text { thousand } \\
\text { people }\end{array}$ & $\begin{array}{c}\text { Year when } \\
\text { CDR was 4 deaths } \\
\text { per 100 thousand } \\
\text { people }\end{array}$ & $\begin{array}{c}\text { Number of years } \\
\text { required to reduce } \\
\text { CDR from 13 to } 4 \\
\text { deaths per 100 } \\
\text { thousand people }\end{array}$ & $\begin{array}{c}\text { CDR in 2017. per } \\
100 \text { thousand } \\
\text { people }\end{array}$ \\
\hline 1 & Norway & 1975 & 2008 & 33 & 2.0 \\
2 & Sweden & 1977 & 2009 & 32 & 2.5 \\
3 & Switzerland & 1989 & 2011 & 22 & 2.7 \\
4 & UK & 1974 & 2009 & 35 & 2.8 \\
5 & Denmark & 1989 & 2011 & 22 & 3.0 \\
6 & The Netherlands & 1981 & 2009 & 28 & 3.1 \\
7 & Israel & 1979 & 2012 & 33 & 3.6 \\
8 & Estonia & 2003 & 2017 & 14 & 3.7 \\
9 & Japan & 1975 & 2014 & 39 & 3.8 \\
10 & Germany & 1987 & 2016 & 29 & 3.9 \\
11 & Spain & 2002 & 2013 & 11 & 3.9 \\
12 & Ireland & 1997 & 2012 & 15 & 3.9 \\
13 & Finland & 1990 & 2017 & 27 & 13.0 \\
14 & Russia & 2017 & 2024 (plan) & 7 (plan) & 3.9 \\
\hline
\end{tabular}

Source: calculated according to (IRTAD 2018) and the Russian police.

\section{THE STRUCTURE AND DYNAMICS OF ROAD TRAFFIC MORTALITY IN RUSSIA}

Prior to the early 1980s, road traffic mortality grew steadily. In the period from 1981 to 1983 , the fight against traffic violations was intensified and fines were increased. This, possibly in combination with the anti-alcohol campaign in the second half of the 1980s, led to a reduction in road traffic mortality. After the abolition of the campaign, road traffic death rates skyrocketed, reaching a historic maximum in 1991. Researchers attribute the mortality increase in this period, specifically pedestrian mortality, to the growth of the level of motorization and the weakening of police control (Luneev 2005).

According to police data, CDR from RTA for 2014-2017 significantly decreased (from 19 to 13 deaths per 100 thousand people). Such an intense decrease is not unique. In some countries it was even faster: in Japan over 2 years, in the Netherlands over 3 years, in Australia and Portugal over 4 years (IRTAD 2018). In addition, CDR equal to 19 deaths per 100 thousand people had been observed in Russia in 1976, 1983, 1997 and 2009. If we take any of these dates as a reference point, then the period of mortality decline from 19 to 13 deaths per 100 thousand people becomes much longer. 


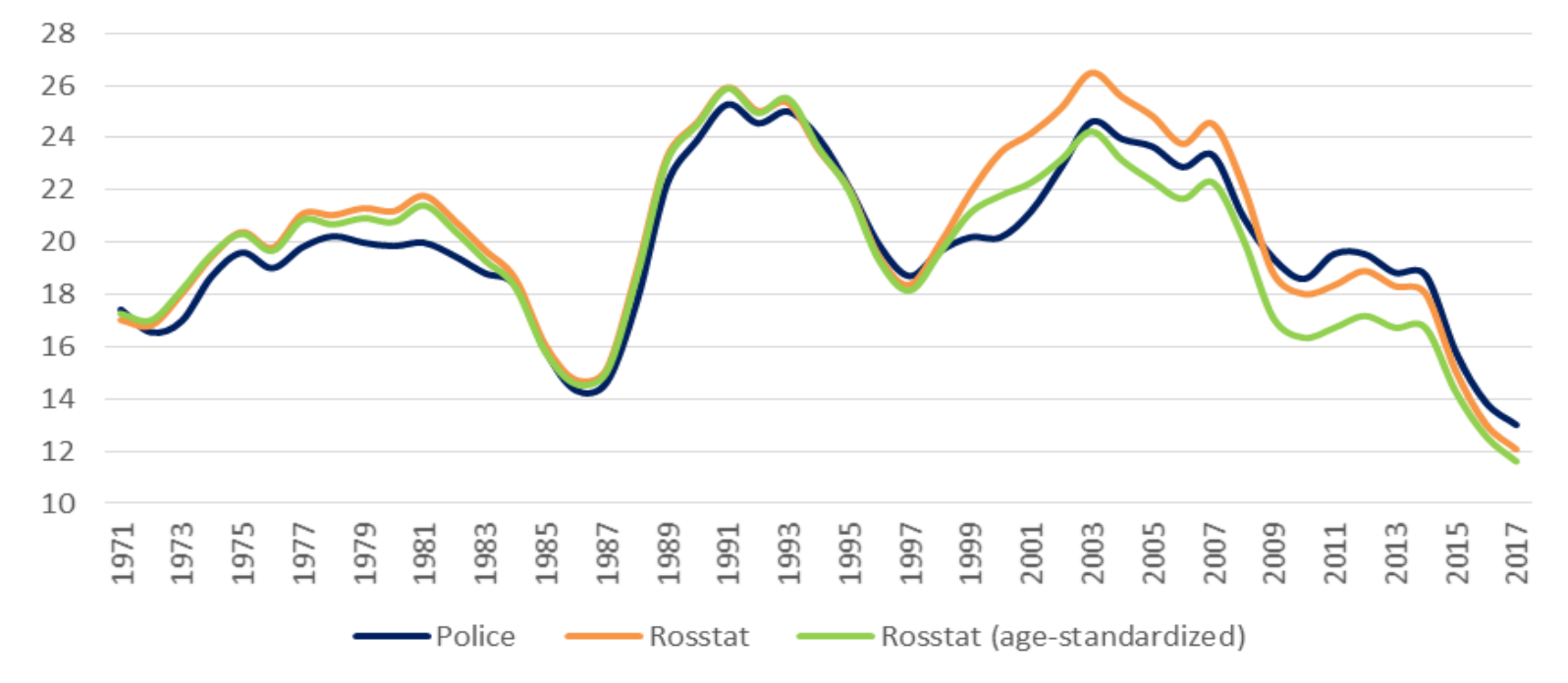

Figure 3. Death rates due to road traffic accidents in Russia according to the police (crude death rate) and Rosstat (crude and age-standardized death rates), per 100 thousand people

Note: Aggregation of causes of death by a group of codes related to "motor vehicle traffic accidents".

Source: Until 1998 data are from RusFMD (Russian Economic School 2019), since 1999 - unpublished data from Rosstat.

One of the targets of RSS is an "increasing protection of the most vulnerable road users, especially children and pedestrians, against road traffic accidents and their consequences ". Indeed, there has been a steady decrease in the ASDR of pedestrians, but it had actually started back in the early 1990s, even before the beginning of the first federal target program (Figure 4). During this period, the ASDR of drivers and passengers was lower corresponding figures for pedestrians by about 2 times. In 1998 it began to increase, exceeding the pedestrian mortality rate in 2000 and reaching a maximum level in 2007. The first stage of mortality reduction of drivers and passengers occurred in 2007 - 2011. It coincided with the introduction and intensification of alcohol control policy in Russia, as well as with the adoption of some legislative acts defining a new procedure for interaction between the police and drivers suspected of drinking and driving (Burtsev et al. 2019). As was shown, adoption of the new alcohol control policy influenced the reduction of transport-related mortality in men positively (Pridemore et al. 2013). The second stage of road traffic mortality reduction of drivers and passengers started in 2014 and is still ongoing. During this period, drinking and driving legislation was toughened, specifically if it resulted in a corresponding fatality ${ }^{12}$.

${ }^{12}$ Article 264.1 of the Criminal Code. 


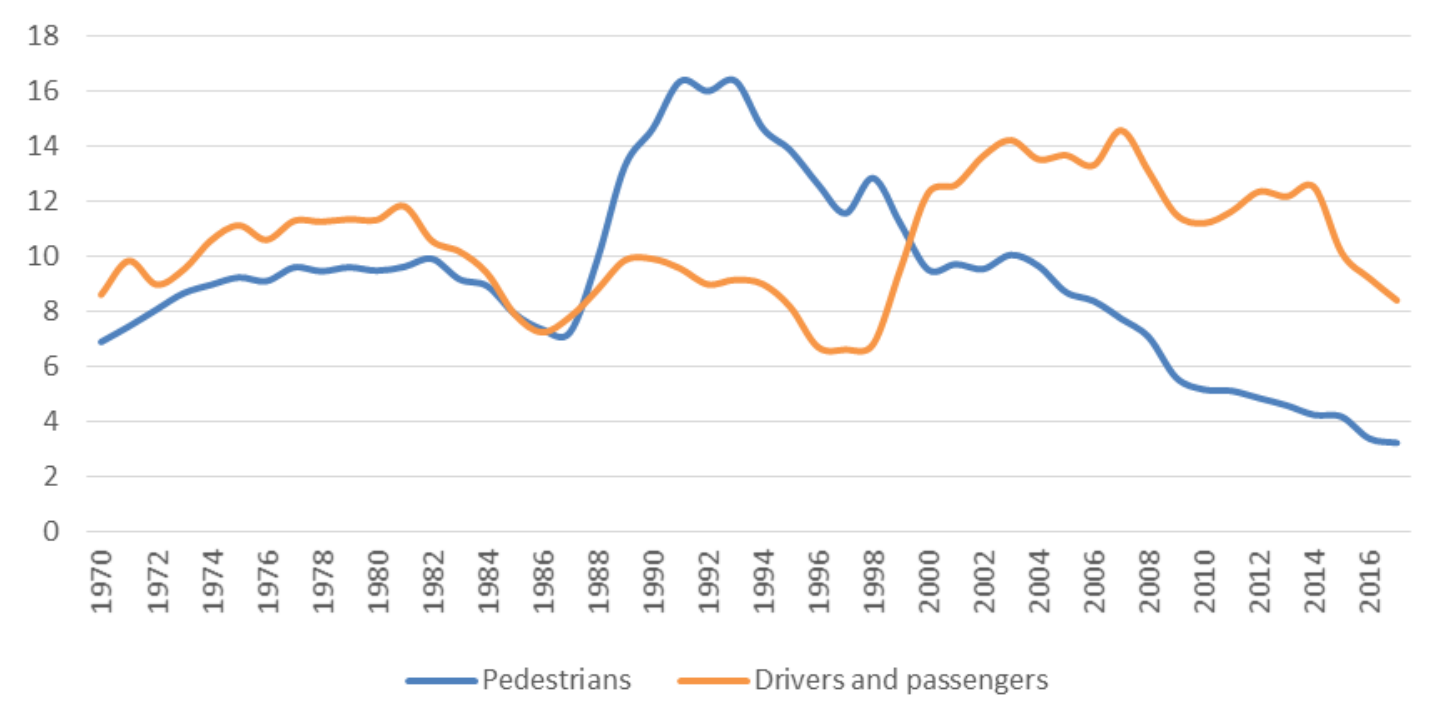

Figure 4. Age-standardized death rates due to road traffic accidents by road users types, per 100 thousand people

Note: see note to figure 3.

Source: Until 1998 - data from RusFMD (Russian Economic School 2019), since 1999 - unpublished data from Rosstat.

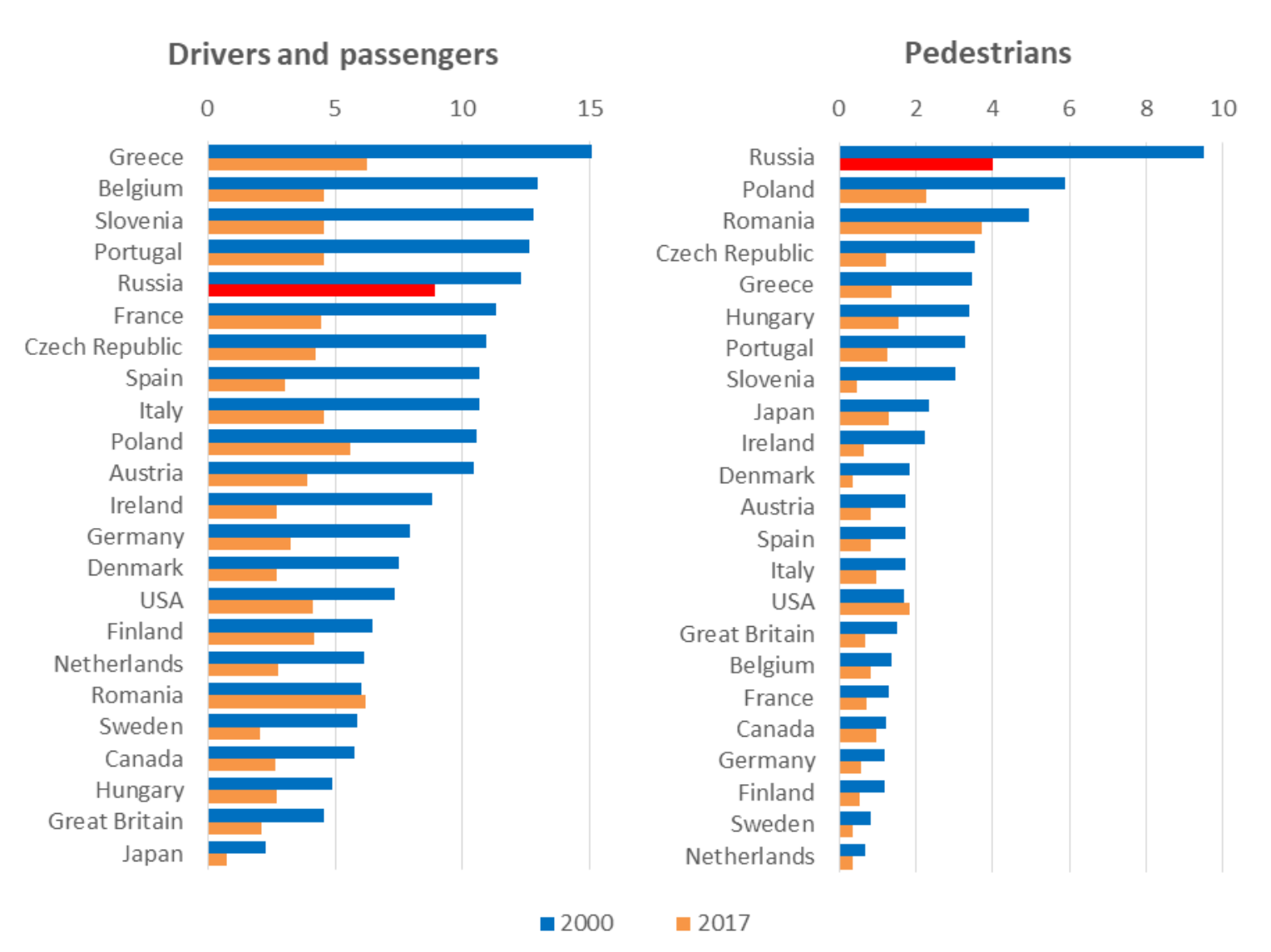

Figure 5. CDR by road user types in some countries in 2000 and 2017, per 100 thousand people

Source: (IRTAD 2018), police data. 
Despite the positive trends and tremendous progress in reducing pedestrian mortality, Russia's lag behind other countries remains significant. The CDR of drivers and passengers in 2017 (8.9 deaths per 100 thousand people) was the highest among the countries shown in Figure 5. In neighboring countries (Poland, Greece, Romania), CDR varies from 5.6 to 6.2 deaths per 100 thousand people. Concerning pedestrian mortality, Russia's lag behind these countries is less, but the gap with the vanguard countries (Sweden, the Netherlands) is tenfold.

Pedestrian age-specific mortality rates increase with age, peaking at the oldest ages. The most rapid increase is from age 0 to 39 years and after 75 years, while in the age group of 4074 years they are almost stable (Figure 6). For drivers and passengers, the age profile of mortality is fundamentally different: a sharp increase, starting from age 15 , with a peak between the ages of 25 and 29 years old and then a gradual decrease with increasing age. Since different categories of road users in different age groups are exposed to different risks of death, the emphasis in formulating road safety policies should take these features into account.

Starting in the 1990s a steady decrease in the standardized pedestrian mortality rate occurred in different age groups with different intensities (Figure 7, left panel). The steepest decline was observed in the youngest age group (0-14 years old), where a 10-fold reduction occurred - from 20 to 2 deaths per 100 thousand people of this age in 1991 - 2017. With increasing age, the pace of the reduction of pedestrian mortality slowed down. Thus, in the age groups 15-29, 30-44, 45-59 and 60+, characterized by higher mortality rates, the age-specific mortality rate for the period 1991-2017 decreased by 7.5, 5.0, 4.0 and 3.6 times, respectively.

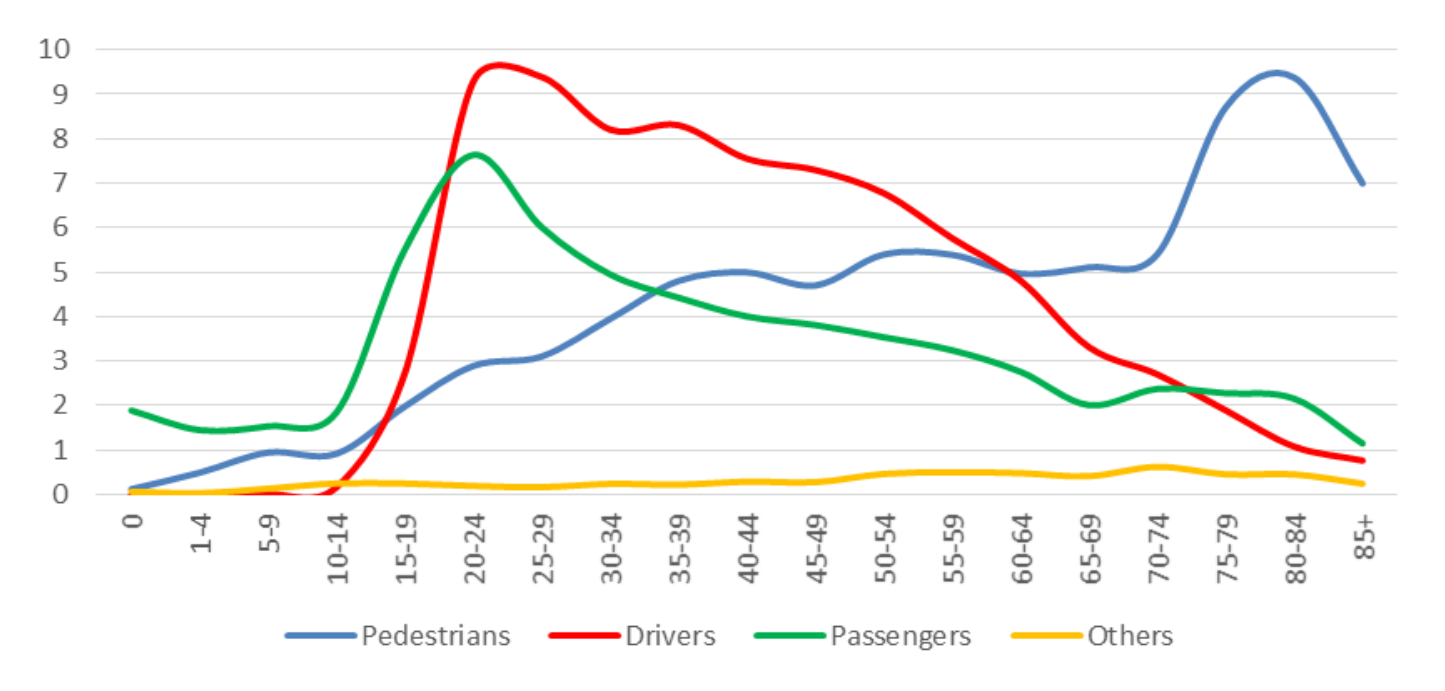

\section{Figure 6. Age-specific death rates by road user types in Russia, 2017, per 100 thousand people}

\section{Source: police data.}

The age-specific mortality rates of drivers and passengers decreased less intensively within all age groups (Figure 7, right panel). There is no such a shift compared with pedestrians. An uninterrupted mortality reduction for drivers and passengers among all age groups has been observed since 2007. The greatest decrease occurred among children (0-14 years old) and young drivers and passengers aged 15-44 years, for whom age-specific mortality rates decreased by 2 times in 2007-2017. 


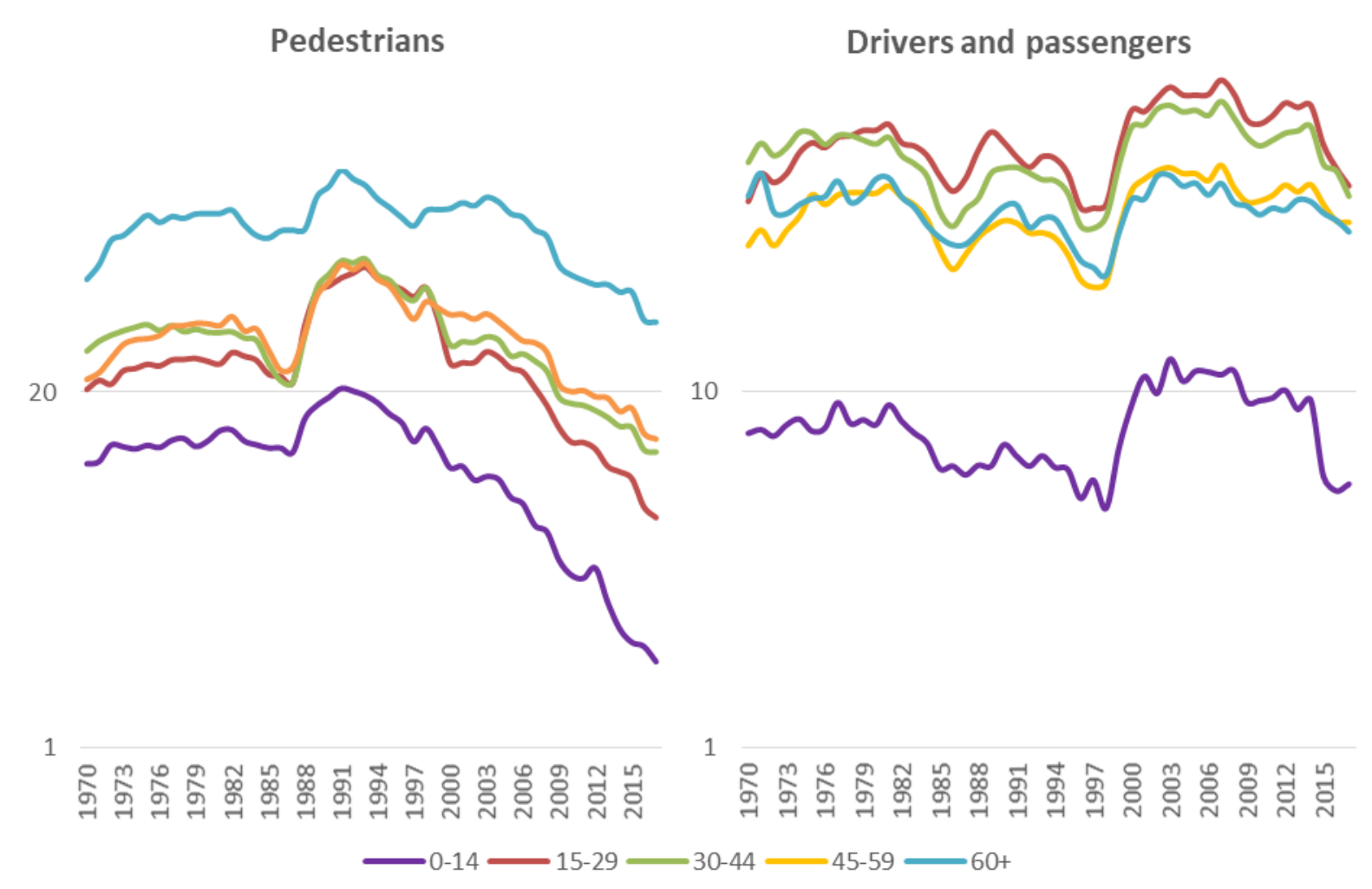

Figure 7. Dynamics of age-specific death rates by main road user types in Russia, per 100 thousand people (log scale)

\begin{abstract}
Note: Aggregation of causes of death according to a group of codes related to "motor vehicle traffic accidents".
\end{abstract}

Source: Until 1998 - data from RusFMD (Russian Economic School 2019), since 1999 - unpublished data from Rosstat.

Regarding child mortality in road traffic accidents, it is important to note that its decrease from 1993 to 2013 was primarily due to a decrease in pedestrian child mortality (Figure 7, left panel). Mortality of child passengers, however, did not decrease (Figure 7, right panel), despite harsher punishment for violating the rules for transporting children in a car ${ }^{13}$. Currently, the mortality of child passengers is 2.5 times higher than the mortality of child pedestrians. This is due to adult behavior, since child passengers under 14 years are passive road users. In addition, the proportion of people using child restraints for transporting a child in their own car is still low in Russia compared to other European countries - only about 50\% (WHO 2018a).

\title{
THE SPATIAL DIMENSION OF ROAD TRAFFIC MORTALITY IN RUSSIA
}

Unfortunately, there is no spatial differentiation of targets in the Road Safety Strategy. However, there are regions in Russia now where the targeted level of road traffic mortality has already been achieved (according to police data, in Moscow and St. Petersburg). Simultaneously, there are regions where reducing road traffic mortality to the target value seems to be a difficult task, given

${ }^{13}$ The Code of the Russian Federation on administrative offenses of December 301, 2001 No. 195-FZ (as amended on June 17, 2019). 
its current high level: the Republics of Kalmykia, Tyva, Adygea, Magadanskaya and Leningradskaya oblast and Zabaikalsky kray (more than 20 deaths in RTA per 100 thousand people).

The reduction in the pace of road traffic mortality in these regions did not depend on its level in 2003, when the tempo of CDR reduction accelerated. If we divide all the regions of Russia into three groups according to the road traffic mortality level in 2003 (more than 25, from 15 to 25, fewer than 15 deaths in RTA per 100 thousand people), it turns out that the reduction of road traffic mortality in groups in 2003-2018 was the following: by 43, 45 and 46 p.p., respectively. Moreover, within regions with positive road traffic mortality dynamics there were ones where the CDR was very high in 2003 (more than 30 deaths per 100 thousand people in the Moscow region, Tverskaya and Vladimirskaya oblasti), and vice versa (below 13 deaths per 100 thousand people in Moscow city, St. Petersburg).

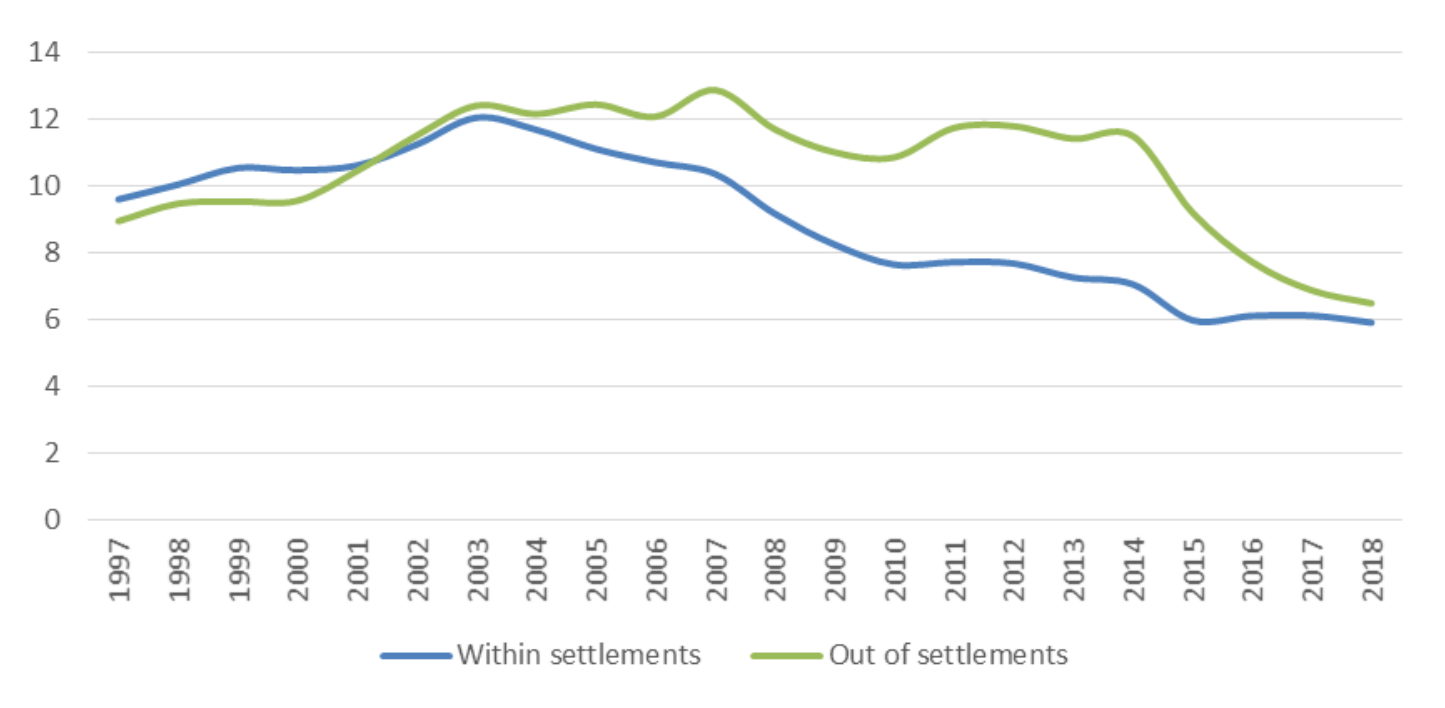

Figure 8. Dynamics of the crude death rate due to road traffic accidents, depending on the place of accident, per 100 thousand population

Source: Police data.

In addition to the place of the accident, also important is whether a person died within or outside of a settlement. During the period of rapid motorization the number of deaths in RTA within settlements was greater than outside them. Starting in 2002 this ratio went in the opposite direction. Since 2000, the proportion of deaths in settlements to the total number of deaths in RTA has been steadily declining, reaching a minimum of $38 \%$ in 2014 , stabilizing afterwards and remaining virtually unchanged during 2015-2018.

The lowering of the CDR in road traffic accidents during 2003 - 2014 occurred mainly in populated areas, while it did not change until 2014 outside of settlements (Figure 8). Since then the reduction of road traffic mortality in populated areas has slowed, while outside of them it has accelerated.

There is also a differentiation of road traffic mortality within the urban-rural dichotomy. In 2015 road traffic mortality in urban settlements was higher than in rural ones; by 2017 the situation had reversed. During this period, road traffic mortality in urban areas decreased, while in 
rural areas it grew (table 3). The decrease of road traffic mortality took place in cities with a population of more than 250 thousand people, but most rapidly in cities with a population of over one million. The dynamics of the indicator in cities with a population of less than 250 thousand people more similar to those in rural areas.

Table 3. The number of deaths and the crude death rate due to road traffic accidents in cities with different populations and rural settlements in Russia

\begin{tabular}{|c|c|c|c|c|c|c|}
\hline & \multicolumn{5}{|c|}{ In cities } & \multirow{3}{*}{$\begin{array}{l}\text { In rural municipalities } \\
\text { and rural areas in urban } \\
\text { municipalities }\end{array}$} \\
\hline & \multirow[b]{2}{*}{ Total } & \multicolumn{4}{|c|}{ with a population of } & \\
\hline & & $\begin{array}{l}\text { Over } 1 \\
\text { million } \\
\text { people }\end{array}$ & $\begin{array}{c}250-999 \\
\text { thousand } \\
\text { people }\end{array}$ & $\begin{array}{c}100-249 \\
\text { thousand } \\
\text { people }\end{array}$ & $\begin{array}{c}\text { Fewer than } \\
100 \text { thousand } \\
\text { people }\end{array}$ & \\
\hline \multicolumn{7}{|c|}{ Number of deaths, people } \\
\hline 2015 & 6892 & 2001 & 2018 & 932 & 1941 & 1860 \\
\hline 2016 & 6526 & 1516 & 1799 & 1011 & 2200 & 2438 \\
\hline 2017 & 6458 & 1444 & 1816 & 1028 & 2170 & 2533 \\
\hline \multicolumn{7}{|c|}{ The number of deaths per 100 thousand people } \\
\hline 2015 & 6.3 & 6.0 & 7.1 & 6.4 & 5.8 & 5.0 \\
\hline 2016 & 6.0 & 4.6 & 6.3 & 7.0 & 6.6 & 6.5 \\
\hline 2017 & 5.9 & 4.4 & 6.4 & 7.1 & 6.5 & 6.8 \\
\hline
\end{tabular}

Source: Calculated according to police and Rosstat data.

Thus, the larger the city, the lower the road traffic mortality rate. This is true both for most European countries and for Russia as a whole (table 4).

Table 4. The crude death rate from road traffic accidents in cities with different populations in some European countries, groups of countries and in Russia, per 100 thousand population

\begin{tabular}{l|c|c|c|c}
\hline & \multicolumn{3}{c}{ Cities with a population of: } \\
\cline { 2 - 5 } & $\begin{array}{c}\text { Over 1 } \\
\text { million } \\
\text { people }\end{array}$ & $\begin{array}{c}250-999 \\
\text { thousand } \\
\text { people }\end{array}$ & $\begin{array}{c}100-249 \\
\text { thousand } \\
\text { people }\end{array}$ & $\begin{array}{c}\text { Fewer than } \\
100 \text { thousand } \\
\text { people }\end{array}$ \\
\hline UK (2017) & 1.8 & 1.8 & 1.9 & 2.5 \\
Germany (2016) & 1.6 & 1.9 & 2.4 & 3.0 \\
Spain (2016) & 1.9 & 2.0 & 2.1 & 2.2 \\
Italy (2017) & 3.9 & 3.9 & 5.1 & 5.1 \\
France (2015) & 1.9 & 2.5 & 2.9 & 3.5 \\
Sweden (2018), Norway (2013), Finland (2017) & 0.9 & 1.4 & 1.9 & 2.2 \\
Bulgaria (2017), Czech Republic (2016), Estonia & & & \\
(2017), Latvia (2017), Lithuania (2017), Hungary & 3.2 & 3.4 & 4.8 & 5.5 \\
(2017), Poland (2014), Slovenia (2017), Slovakia (2017) & & & \\
Belgium (2016), The Netherlands (2013), Ireland & 1.4 & 2.6 & 2.6 & 1.9 \\
(2011). Switzerland (2016) & 4.4 & 6.4 & 7.1 & 6.5 \\
Russia (2017) & & & \\
\hline
\end{tabular}

Source: Calculated according to (Eurostat 2019), Russia - according to the police.

On the one hand, in the Russian million-plus cities the targets for reducing mortality by 2024 were already achieved in 2017, using police data. Therefore, cities with a smaller population should become policy priorities in the field of road safety. On the other hand, the crude death rate from road traffic accidents in Russian million-plus cities is unacceptably high compared with similar cities in Great Britain, Germany, Spain, France, and the countries of Northern Europe. It is comparable only with million-plus cities in Italy and Eastern Europe. In many European million- 
plus cities (Berlin, Paris, London, Stockholm, etc.) with a comparable motorization level (an average of 329 cars per 1000 population), the road traffic mortality rate is 1.9 deaths per 100 thousand people, whereas in Russia it is 2.3 times higher.

The significant spatial road traffic mortality differentiation in Russia is, possibly, partly attributable to the settlement pattern, the urbanization rate and the level of road network connectivity of the region. For million-plus cities, the goals of reducing road traffic mortality could be more ambitious, since the potential for reduction in them has not been exhausted. Based on international experience and ongoing Russian trends, road traffic mortality in large and mediumsized cities of Russia should be 1.5-2 deaths per 100 thousand people, and in small cities and rural settlements - 2.5-3 deaths per 100 thousand people. Only with such mortality rates in cities and rural settlements and with the mortality rate outside populated areas maintained at the same level is it possible to achieve CDR of 4 deaths per 100 thousand people.

\section{LIMITATIONS}

The study was not without limitations. In this work, we considered the consistency of road traffic mortality only with the targets set in the first Road Safety Strategy, leaving outside our scope legislative changes in other areas, such as the administrative and criminal codes, adopted national alcohol control policy, drinking and driving policy, changes in the healthcare system, etc. Focusing on RSS seemed justified, as this document sets out a fundamental vision on road traffic mortality and outlines targets for its reduction.

Using police data for international comparisons, the crude death rates are not agestandardized due to the limitation of the IRTAD database, which does not provide users a distribution of the number of deaths by gender and age.

There is no sex-specific analysis of road traffic mortality, as it was outside the scope of our objectives. But such a differentiation exists in Russia, and it is quite significant.

The category of "cyclists" was not separated due to the difficulty of distinguishing it in vital statistics and police data for the entire time period under study. Given the small number of cyclists who have died in Russia (392 deaths in 2016), we believe that this only slightly affected the mortality trends of unprotected road users, a category which usually includes cyclists.

The dynamics of the number of deaths and the crude death rate in road traffic accidents in cities and rural settlements are presented for a short period of time (only 3 years), which is explained by the depth of the open source police archive.

All assessments of the number of deaths based on vital statistics are given without taking into account the possible impact of the so-called "garbage" codes of causes of death ${ }^{14}$. Of these, codes that could influence the statistics of deaths from accidents include codes of the ICD-10

\footnotetext{
14 The concept of "garbage" codes of causes of death was introduced in 1990 by Nagavi and Lopez in the Global Burden of Disease project. A "junk" cause of death code is a code that cannot or should not be used as the original cause of death (Murray CJL, Lopez A.D. 1996). Then the concept of "junk" codes was expanded by them, and their classification was given (Naghavi, Makela, Foreman et al. 2010).
} 
heading such as "injuries with uncertain intentions" (Y10-Y34). WHO has adopted the concept of "garbage codes" and includes Y10-Y34 in its short list of "garbage" codes (World Health Organization 2014: 4). Forensic experts using "garbage" codes to code deaths still occurs in Russia (Pyankova et al. 2019). If we adjust the number of deaths in road traffic accidents based on vital statistics for these codes, road traffic mortality will increase, thus reducing the discrepancy between police data and vital statistics on the number of deaths in road traffic accidents.

\section{Conclusion}

A consideration of road traffic mortality as a completely preventable cause of death is reasonable. However, the timelines set in the Russian Road Safety Strategy for 2018-2024 are very tight, in terms of international experience and the existing mortality rate. There have been no precedents of road traffic mortality reduction by 3.5 times in 7 years in other countries.

The Road Safety Strategy prioritizes the reduction of road traffic mortality of children and pedestrians. The mortality rate within both groups has recently decreased most intensively compared to other categories of road users. At the same time, the main risk groups for many years have been drivers and passengers aged 15-44 years old and pedestrians over 60 years old. However, while among pedestrians a decrease in mortality seems to be a steady trend with no visible signs of leveling off, for drivers and passengers it is not so obvious.

The achievement of target indicators in the framework of monitoring the implementation of the Road Safety Strategy must be considered differentially, both by type of region depending on the existing level, and by the scene of the accidents (in or outside of settlements). At present, it is possible to achieve the targets of the Road Safety Strategy for 2018-2024 only in cities with a large and medium population.

For a precise definition of the category of road traffic accident deaths based on vital statistics, the very first step may be to abandon the present approach based on the Russian abridged classification of causes of death and switch to one of the two international options for aggregating three-digit ICD-10 codes used by WHO to determine the number of deaths in road traffic accidents. This will lead to the elimination of the existing significant discrepancies between the published figures in the two official reporting systems, but will not completely eliminate them. Given the fact that forensic experts in Russia attribute a significant number of deaths from road traffic accidents to non-traffic or unspecified as traffic or non-traffic accidents, it makes no sense to use the four-digit code sample also proposed by WHO. This will again lead to an underestimation of the number of deaths in "road traffic accidents". In this case, the easily solved problem of switching to one of the international approaches of aggregating cause of death codes is confronted with the more complex problem of accurately determining the circumstances of the accident by forensic experts in the context of a fully decentralized coding system in Russia and the absence of two-way effective communication with police officers.

At the same time, within the framework of the police reporting system it is advisable to keep a separate record of accidents not corresponding to the concept of road traffic accidents from the Glossary for Transport Statistics, and subsequently not include them in the official number of deaths in road traffic accidents according to police data. 
Strengthening interagency cooperation between the police and the state death registration system may result in the possibility of either preliminary coding of the circumstances of the accident in the ICD-10 language by the police when filling out the accident report, or the possibility of correcting the circumstances of the accident when interacting with the forensic medical experts. It is also necessary to establish a system of bilateral information exchange with them, both with the aim of improving the quality of coding of this cause of death in the medical death certificate and reducing the number of deaths due to accidents unspecified as traffic or nontraffic, and to exclude deaths from natural causes in the police reporting system.

However, the scientific community still has certain concerns related to a possible change in the quality of registration of deaths due to road traffic accidents and its consequences for vital statistics in the coming years. For example, it happened with diseases of the circulatory system after the Russian President declared 2015 the year of the fight against cardiovascular diseases (Vishnevsky, Andreev, Timonin 2016).

\section{REFERENCES}

Bakanov K.S. (2019, May). Improvement of statistics on fatalities in road accidents. Report presented at the meeting of the working group on monitoring key road safety indicators in the Russian Federation, WHO Regional office for Europe, Russia, Moscow. (In Russ.).

Burtsev A.A., Kirzhanova V.V., Grigorova N.I., Bakanov K.S. (2019). Main trends of medical examination indicators on the state of drinking in the Russian Federation in 2004-2017. Narcology, 18(4), 3-17. doi: 10.25557/1682-8313.2019.04.3-17 (In Russ.).

Danilova I., Shkolnikov V.M., Jdanov D.A., Meslé F., Vallin J. (2016) Identifying potential differences in cause-of-death coding practices across Russian regions. Population health metrics, 14(8), 1-20. doi:10.1186/s12963-016-0078-0

Danilova I.A. (2015). Specific features of the reconstruction of continuous cause-specific mortality time-series for Russia. Voprosy statistiki, 11, 58-68. doi: 10.34023/2313-63832015-0-11-58-68 (In Russ.).

European Commission (2017). Annual accident report 2017. European Commission, Directorate General for Transport. URL:

https://ec.europa.eu/transport/road_safety/sites/roadsafety/files/pdf/statistics/dacota/asr2017. $\operatorname{pdf}(13.09 .2019)$

Eurostat (2019). Regions and cities; People killed in road accidents (per 10000 population) 2017. Available at https://ec.europa.eu/eurostat/cache/RCI/\#?vis=city.statistics\&lang=en (22.04.2019)

Federal State Statistics Service (2017). The Demographic Yearbook of Russia 2017. Statistical handbook. Moscow: Rosstat.

IRTAD (2018). Road safety annual report 2018. International traffic safety data and analysis group. URL: https://www.itf-oecd.org/sites/default/files/docs/irtad-road-safety-annual-report2018_2.pdf (13.09.2019)

Luneev V.V. (2005) Prestupnost XX veka: mirovye, regionalnye i rossijskie tendencii. Moscow: Voltet Kluver. 
Meslé F., Shkolnikov V., Hertrich V., Vallin, J. (1996). Recent trends in mortality by causes of death in Russia during 1965-1994. Paris-Moscow. URL:

http://www.demoscope.ru/weekly/knigi/shkol/shkol.html (In Russ.) (13.09.2019)

Murray CJL, Lopez A.D. (eds.). (1996). The Global Burden of Disease and Injury 1: A comprehensive assessment of mortality and disability from diseases, injuries, and risk factors in 1990 and projected to 2020. London, UK: Harvard University Press on behalf of the World Health Organization and World Bank.

Naghavi M., Makela S., Foreman K. et al. (2010). Algorithms for enhancing public health utility of national causes-of-death data. Population health metrics, 8(1), 9.

doi: $10.1186 / 1478-7954-8-9$

New economic school (2019). Russian Fertility and Mortality Database. Russia, causes of death, 5-year age groups, 1959-1988; Russia and regions, causes of death, 5-year age groups, 1989-1998 . Available at http://demogr.nes.ru/index.php/ru/demogr_indicat/data (22.04.2019).

Pridemore W., Chamlin M. B., Kaylen M. T., Andreev E. (2013). The impact of a national alcohol policy on deaths due to transport accidents in Russia. Addiction, 108, 2112-2118. doi:10.1111/add.12311

Pyankova A.I, Fattakhov T.A., Bakanov K., Yurasova E.D. (2019). Road traffic mortality in Moscow: record linkage study using police data and vital statistics. Demographic review, 6(1), 151-176. doi: 10.17323/demreview.v6i1.9115. (In Russ.)

UN Road Safety Collaboration (2010). White paper for safe roads in 2050. Achieving Zero Work-Related Road Deaths. URL:

https://www.who.int/roadsafety/events/unrsc_12_appendix_11.pdf (13.09.2019)

UNECE UN (2009). The Glossary for Transport Statistics. Retrieved from https://www.unece.org/fileadmin/DAM/trans/main/wp6/pdfdocs/glossen4.pdf (13.09.2019)

Vishnevsky A.G., Andreev E.M., Timonin S.A. (2016). Mortality from cardiovascular diseases and life expectancy in Russia. Demographic review, 3(1), 6-34. doi:10.17323/demreview.v3i1.1761. (In Russ.).

World health organization (WHO) (2014). WHO methods and data sources for country-level causes of death 2000-2012. Geneva: WHO. URL:

https://www.who.int/healthinfo/global_burden_disease/GlobalCOD_method_2000_2012.pdf (13.09.2019)

World health organization (WHO) (2018b). WHO methods and data sources for country-level causes of death 2000-2016. Geneva. URL:

http://terrance.who.int/mediacentre/data/ghe/GlobalCOD_method_2000_2016.pdf?ua=1 (13.09.2019)

World health organization (WHO) (2018a). Global status report on road safety 2018. Geneva. 


\section{APPENDIX}

Table A1. The division of transport accidents in the short list of causes of death in ICD-9 and in Soviet Abridged Classifications (SCs) of causes of death during ICD-9

\begin{tabular}{|c|c|c|}
\hline RC-items & Russian name of RC-items & English name of RC-items \\
\hline \multicolumn{3}{|c|}{ Short list of causes of death ICD-9 } \\
\hline E471 & $\begin{array}{l}\text { Происшествия с участием автомобильного } \\
\text { транспорта }\end{array}$ & Motor vehicle traffic accidents \\
\hline E472 & $\begin{array}{l}\text { Происшествия с другими с дорожными } \\
\text { транспортными средствами }\end{array}$ & Other road vehicle accidents \\
\hline $\mathrm{E} 470$ & Железнодорожные происшествия & Railway accidents \\
\hline E473 & Аварии на водном транспорте & Water transport accidents \\
\hline E474 & Авиационные и космические аварии & Air and space transport accidents \\
\hline \multicolumn{3}{|c|}{ SC in use from 1981 to 1987.} \\
\hline 160 & $\begin{array}{l}\text { Несчастные случаи, связанные с } \\
\text { мототранспортом, исключая случаи на } \\
\text { производстве }\end{array}$ & $\begin{array}{l}\text { Motor vehicle traffic accident, excluding } \\
\text { occupational }\end{array}$ \\
\hline 161 & $\begin{array}{l}\text { Автомототранспортный несчастный случай на } \\
\text { общественной дороге в результате наезда на } \\
\text { пешехода }\end{array}$ & $\begin{array}{l}\text { Motor vehicle traffic accident involving } \\
\text { collision with pedestrian }\end{array}$ \\
\hline 162 & $\begin{array}{l}\text { Несчастные случаи, связанные с } \\
\text { мототранспортом, случаи на производстве }\end{array}$ & Motor vehicle traffic accident, occupational \\
\hline 163 & $\begin{array}{l}\text { Автомототранспортные несчастные случаи, } \\
\text { исключая случаи на производстве }\end{array}$ & $\begin{array}{l}\text { Accidents involving other types of transport, } \\
\text { excluding occupational }\end{array}$ \\
\hline 164 & $\begin{array}{l}\text { Автомототранспортные несчастные случаи, } \\
\text { случаи на производстве }\end{array}$ & $\begin{array}{l}\text { Accidents involving other types of transport, } \\
\text { occupational }\end{array}$ \\
\hline \multicolumn{3}{|c|}{ SC in use from 1988 to 1998} \\
\hline 160 & $\begin{array}{l}\text { Несчастные случаи, связанные с } \\
\text { мототранспортом }\end{array}$ & Motor vehicle traffic accident \\
\hline 161 & $\begin{array}{l}\text { Автомототранспортный несчастный случай на } \\
\text { общественной дороге в результате наезда на } \\
\text { пешехода }\end{array}$ & $\begin{array}{l}\text { Motor vehicle traffic accident involving } \\
\text { collision with pedestrian }\end{array}$ \\
\hline 162 & Автомототранспортные несчастные случаи & Other transport accidents \\
\hline
\end{tabular}




\section{Table A2. The division of transport accidents ( $V$-codes) in Russian Abridged Classifications (RCs) of causes of death during ICD-10}

\begin{tabular}{l|c|c}
\hline RC-items & Russian name of RC-items & English name of RC-items \\
\hline \multicolumn{2}{|c}{ RC in use in the period 1999-2005 }
\end{tabular}

Пешеход, пострадавший в результате транспортного несчастного случая

Лицо, находившееся в легковом автомобиле,

пострадавшее в результате транспортного несчастного случая

Другие и неуточненные транспортные несчастные случаи Other and unspecified transport accidents $R C$ in use in the period 2006-2010.

Пешеход, пострадавший в результате транспортного несчастного случая

Пешеход, пострадавший от внедорожного

мототранспортного несчастного случая

Лицо, находившееся в легковом автомобиле,

пострадавшее в результате транспортного несчастного случая

Другие и неуточненные транспортные несчастные случаи

Другое лицо, пострадавшее от внедорожного мототранспортного несчастного случая Другие транспортные несчастные случаи

\section{$R C$ in use in the}

Pedestrian injured in transport accident

Car occupant injured in transport accident

Pedestrian injured in transport accident

Pedestrian injured in collision with motor vehicle, nontraffic accident

Car occupant injured in transport accident

Occupant of other transport vehicle in transport accident

Other persons injured in collision with motor vehicle, nontraffic accident

Other transport accidents

Пешеход, пострадавший в результате дорожного транспортного случая

Пешеход, пострадавший в результате недорожного транспортного случая (кроме железнодорожного) Пешеход, пострадавший в результате неуточненного транспортного случая (кроме железнодорожного) Велосипедист (любой), мотоциклист (любой) и лицо, находящееся в трехколесном транспортном средстве, пострадавшие в результате дорожного транспортного случая

Велосипедист (любой), мотоциклист (любой) и лицо, находящееся в трехколесном транспортном средстве, пострадавшие в результате недорожного транспортного случая

Лицо, находившееся в автотранспортном средстве, пострадавшее в результате дорожного транспортного случая

Лицо, находившееся в автотранспортном средстве, пострадавшее в результате недорожного транспортного случая

Пешеход, пострадавший при столкновении с поездом или другим железнодорожным транспортным средством Другие и неуточненные транспортные несчастные случаи Погружение в воду и утопление в результате аварии на водном транспортном средстве

Погружение в воду и утопление, связанное с водным транспортом, не связанное с аварией на нем

Другие и неуточненные несчастные случаи на водном транспорте

Несчастные случаи на воздушном транспорте и при космических полетах
Pedestrian injured in road traffic accident (except rail)

Pedestrian injured in nontraffic accident (except rail)

Pedestrian injured in unspecified transport accident (except rail)

Cyclist (any), motorcyclist (any) and occupant of a three-wheeled vehicle, injured in road traffic accident

Cyclist (any), motorcyclist (any) and occupant of a three-wheeled vehicle, injured in nontraffic accidents

Person in vehicle injured in road traffic accident

Person in vehicle injured in nontraffic accident

Pedestrian injured in a collision with a train or other railway vehicle

Other and unspecified transport accidents Immersion in water and drowning in an accident on a watercraft

Immersion in water and drowning related to water transport but not associated with an accident on it

Other and unspecified accidents in water transport

Accidents in air transport and space travel 